\title{
SPRAWOZDANIE Z VII KONGRESU TEOLOGÓW POLSKICH W KATOLICKIM UNIWERSYTECIE LUBELSKIM, LUBLIN 12-15.09.2004
}

Wielkim świętem teologii można nazwać VII Kongres Teologów Polskich, który odbył się w Katolickim Uniwersytecie Lubelskim w dniach 12-15 września 2004 r. Został on zwołany z inicjatywy Rady Naukowej Konferencji Episkopatu Polski, a zorganizowany przez KUL przy współpracy polskich fakultetów teologicznych. W obradach uczestniczyli kardynałowie, arcybiskupi, biskupi oraz kilkuset teologów z całej Polski i z zagranicy (z Włoch, Niemiec, Francji, Słowacji, Litwy i Ukrainy). W ciągu 4 dni można było wysłuchać wypowiedzi najwybitniejszych uczonych, polskich i przybyłych z zagranicy.

Wydarzenie kongresu wpisało się w linię programową poprzednich spotkań tej rangi oraz w teologiczną część II Ogólnopolskiego Synodu Plenarnego. Stanowiło, postulowaną przez Jana Pawła II w stosunku do powołania teologów w Kościele i świecie, refleksję nad znakami czasu określającymi rozumienie miejsca Kościoła w życiu społecznym oraz pastoralne zadania wobec nowych wyzwań. Wiodący temat: „Kościół w życiu publicznym. Teologia polska i europejska wobec nowych wyzwań" został poddany wieloaspektowej analizie wszystkich środowisk teologicznych kraju, podzielonej na następujące grupy zagadnień: 12 września - „Chrześcijaństwo wobec wyzwań współczesności”, 13 września - „Teologia a kultura”, 14 września - „Teologiczna antropologia społeczna”, 15 września - „Kościół w sytuacji społeczno-politycznej”. Program merytoryczny został zrealizowany w formie wykładów plenarnych, grup dyskusyjnych, spotkań sekcji teologicznych oraz komunikatów.

W pierwszym dniu kongresu, w części wstępnej, po przywitaniu uczestników przez rektora KUL - ks. prof. Stanisława Wilka, głos zabrał przewodniczący Rady Naukowej Episkopatu Polski - bp Stanisław Wielgus. Wskazał podstawowe cele Kongresu, którymi są: podsumowanie dotychczasowych osiągnięć naukowych, skoncentrowanie się na obecnie realizowanych badaniach oraz wyznaczenie kierunków i obszarów pracy na przyszłość. Papież Jan Paweł II w przesłaniu skierowanym do uczestników obrad napisał: „W obliczu nowych zadań, stawianych dziś przez złożone sytuacje cywilizacyjne i religijne, Kościół, a wraaz z nim teologia stają wobec wezwania nie tylko do 
obrony dziedzictwa chrześcijańskiego, ale także do aktywnego wchodzenia do miejsc życia codziennego i współczesnej cywilizacji, aby na drodze dialogu i ewangelizacji skutecznie głosić prawdę o Bogu żywym i Jego zamyśle zbawienia przez Jezusa Chrystusa”. Wielki Kanclerz KUL - abp Józef Życiński wskazał na niepokojące próby eliminowania religii z życia publicznego.

W pierwszym dniu kongresu abp prof. Bruno Forte w swoim wystąpieniu Chrześcijaństwo europejskie wobec wspótczesnych wyzwań zwrócił uwagę na kryzys świadomości europejskiej, która musi odnaleźć utracony sens. W sytuacji utraty zamiłowania do prawdy, chrześcijanie winni stać się świadkami Ewangelii w służbie pojednania i sługami miłości. Według abp. Forte, chrześcijaństwo nie jest żadną ideologią, ale miłością przezwyciężającą wszelką przemoc. W kolejnym wykładzie Teologia polska wobec wyzwań wspótczesności o. prof. Andrzej Napiórkowski podjął próbę opisu aktualnego stanu polskiej teologii oraz wskazał na jej podstawowe zadania.

W drugim dniu kongresu uwaga uczestników została skoncentrowana na relacji między teologią a kulturą. Ks. prof. Jean Galot wygłosił odczyt Chrystologia a antropologia w kontekście Ewangelii wedtug św. Jana. W następnym wykładzie Naród jako fenomen kultury w ujęciu teologicznym ks. prof. Czesław Bartnik podkreślił, że w okresie współczesnego globalizmu europejskiego i światowego potrzebna jest tzw. teologia narodu. Przedstawił on naród w świetle objawienia chrześcijańskiego. Naród posiada swoją tożsamość, świadomość, niepowtarzalność, jest podmiotem życia religijnego i duchowego. Kościół jest „zapodmiotowany” w narodzie. Jedność kontynentu europejskiego winna dokonywać się pośrednio przez tworzenie wielkiej rodziny narodów. Prof. Lucjan Balter w swoim wystąpieniu poruszył problem promocji polskiej teologii w świecie. Zaznaczył, że język teologii zachodniej niekiedy bywa zbyt hermetyczny, skomplikowany i nie jest zdolny wyrazić polskiego doświadczenia wiary.

W trzecim dniu kongresu wystąpienia prelegentów skupiły się wokół problemu teologicznej antropologii społecznej. Bp prof. Gerhard Ludwig Müller z Regensburga w wykładzie Dialog teologii z kultura postulowat, by Kościół i teologia chroniły prawo ludzi do kultury. W kontekście przemian społecznych teologia musi odnosić się do rodziny, która przez miłość uczy wypróbowanych form kultury ludzkiej. Natomiast kard. prof. Stanisław Nagy w wykładzie Nie można zrozumieć człowieka bez Chrystusa ukazał istotę i przeznaczenie człowieka jako jedną z głównych zagadek dla racjonalnej refleksji. Człowiek, będący istotą nieznaną i tragiczną, dopiero w Chrystusie odnajduje prawdę o sobie samym i $\mathrm{z}$ wielkiej niewiadomej staje się w Chrystusie drugim Adamem, królem, koroną i chwałą stworzenia.

W ostatnim dniu obrad kongresu podjęto refleksję nad misją Kościoła w obecnej sytuacji społeczno-politycznej. Ks. prof. Raúl Berzosa Martínez wygłosił wykład Relacja Kościót-wspólnota polityczna w świetle Soboru Watykańskiego II. Dokonał analizy historyczno-redakcyjnej konstytucji soborowej Gaudium et spes oraz wskazał na podstawowe zasady autonomii 
i współpracy w relacji państwo-Kościół. Ks. prof. Jan Wal w referacie Kościót wobec kwestii spotecznej zaprezentowat rozwój nauczania kościelnego w kwestii spotecznej. Ostatni referat w ramach tegorocznego kongresu został wygłoszony przez ks. prof. Józefa Krukowskiego. W swoim wystąpieniu Kościelne prawo publiczne w Europie i Polsce Ksiądz Profesor omówił m.in. stanowisko Unii Europejskiej wobec religii i wolności religijnej, wskazał na postulaty Kościoła dotyczące poszanowania religii i dziedzictwa chrześcijańskiego w Konstytucji Unii Europejskiej, przypomniał, że w tekście konstytucji z 18 czerwca 2004 r. nie umieszczono odniesienia ani do dziedzictwa chrześcijańskiego, ani do Boga. Pozostawiono natomiast bez zmian gwarancje wolności myśli, sumienia i religii oraz poszanowanie pozycji prawnej Kościołów i organizacji światopoglądowych. Na zakończenie obrad odczytano Stowo do wiernych i ludzi dobrej woli, Przestanie Dziekanów europejskich Wydziatów Teologicznych oraz Deklarację solidarności z teologami Ukrainy, obecnymi na VII Kongresie Teologów Polskich.

Kongres lubelski był okazją do wyrażenia wdzięczności ośrodkom teologicznym na zachodzie Europy. Teologia polska przez długi czas korzystała z teologii zachodniej, a przy tym mogła się też i samodzielnie rozwijać pr'zy jej boku, wnosząc w Kościół uniwersalny swój znaczący wkład. Wdzięczność ta została wyrażona symbolicznie poprzez nadanie Doktoratów Honoris Causa Katolickiego Uniwersytetu Lubelskiego. Doktoraty otrzymali: abp prof. Bruno Forte - metropolita Chieti-Vasto w Abbruzzi we Włoszech, prof. Papieskiego Wydziału Teologicznego św. Tomasza w Neapolu, bp Gerhard Ludwig Müller z Regensburga, prof. Uniwersytetu w Monachium oraz ks. prof. Jean Galot z Rzymu. Laudacje na cześć doktorów honoris causa wygłosili kolejno: ks. prof. Czesław Bartnik, ks. prof. Krzysztof Góźdź oraz ks. prof. Walerian Słomka.

Wart podkreślenia jest fakt uczestnictwa w kongresie dużej grupy teologów ze wschodu (najwięcej z Ukrainy - ok. 100 osób). W dużej mierze byli to absolwenci Katolickiego Uniwersytetu Lubelskiego, a także pracownicy naukowi Katolickiego Uniwersytetu Ukraińskiego i członkowie Ukraińskiego Naukowego Towarzystwa Teologicznego we Lwowie. W drugim dniu kongresu sprawowana była liturgia eucharystyczna w obrządku greckokatolickim, co jeszcze bardziej podkreśliło charakter tego zgromadzenia, jedność i współpracę. Obecność teologów wschodnich jest odpowiedzią na apele Papieża Jana Pawła II, które skierował do Uniwersytetu Lubelskiego (a kiedyś swego uniwersytetu), aby wspierać odradzające się Kościoły na wschodzie Europy.

Kongres teologów stał się też okazją do przeprowadzenia dorocznych spotkań sekcyjnych profesorów teologii różnych specjalizacji. Na spotkaniach tych wygłoszono liczne referaty i przeprowadzono dyskusje pozwalające wypracować pewne propozycje działania na przyszłość. Treść przedstawionych referatów na spotkaniach sekcyjnych można odnaleźć w materiałach wydanych jeszcze przed kongresem.

Podczas kongresu czynne były liczne stoiska wydawnictw kościelnych, które miały bardzo bogatą ofertę wydawniczą. Świadczy to o prężności ośrod- 
ków nauk kościelnych w Polsce. Rozprowadzany był m.in. „Informator” o strukturach i kadrze naukowo-dydaktycznej tych jednostek wraz z wykazem stopni naukowych doktora, doktora habilitowanego i profesora nadanych na wydziałach nauk kościelnych w latach 1987-2003.

VII Kongres Teologów Polskich, który miał miejsce w Lublinie we wrześniu bieżącego roku był niewątpliwie największym spotkaniem środowisk teologicznych ostatnich lat. Ojciec święty skierował do uczestników Kongresu specjalne przesłanie. Przypomniał wnim szczególny wkład teologów w powiązaniu z ludźmi nauki i kultury - w życie publiczne w latach osiemdziesiątych minionego wieku. Podkreślił jednocześnie, że Kościół, a wraz z nim teologia, stają wobec nowych wyzwań nie tylko obrony dziedzictwa chrześcijańskiego, ale także aktywnego wychodzenia ku współczesnej cywilizacji - by na drodze dialogu i ewangelizacji skutecznie głosić prawdę o Bogu Żywym.

Ks. Adam Skreczko 